\title{
Pengaruh Metode Pembelajaran Kerja Kelompok Pada Pelajaran Matematika Terhadap Motivasi Belajar Siswa Di Masa Pandemi Covid-19
}

\author{
Nurdin Muhamad ${ }^{1}$, Ricky Herdian ${ }^{2}$ \\ Program Studi Pendidikan Guru Madrasah Ibtidaiyah, Universitas Garut \\ nurdin@uniga.ac.id
}

\begin{abstract}
Abstrak
Penulisan artikel ini bertujuan untuk memberikan gambaran bahwa pendukung pembelajaran secanggih apapun dan sebaik apapun tanpa didukung oleh lingkungan belajar siswa (teman sejawat, guru, orangtua) yang mengarahkan mereka belajar dengan bagus maka hasilnya tidak akan maksimal. Motivasi merupakan kunci keberhasilan proses pembelajaran, karena sejatinya dapat menunmbuh kembangkan nilai-nilai positif yang dibutuhkannya dalam mempelajari pelajaran secara daring khususnya pada mata pelajaran matematika. Adapun siswa SD/MI membutuhkan dorongan dan rangsangan untuk memunculkan keinginan dalam belajar, salah satunya yaitu belajar bersama teman-temannya dengan batasan prokes dari pemerintah. Dengan dasar tersebut kami mencoba menerapkan pola pembelajaran dengan metode kerja kelompok. Untuk metode kami menggunakan metode penelitian kuantitatif deskriptif, dimana hasinya dapat mengungkapkan dan memecahkan permasalahan yaitu dengan menggambarkan dan memaparkan data sesuai dengan data hasil penelitian. Berdasarkan hasil penelitian tersebut didapatkan bahwa motivasi belajar pada pelajaran matematika dapat dipengaruhi oleh metode pembelajaran kerja kelompok, dengan tingkat hubungan 0,726 kategori kuat. Adapun besar pengaruh yang didapatkan adalah sebesar $52,71 \%$ sedangkan sisanya sebesar $47,29 \%$ dipengaruhi oleh variabel lain yang tidak diteliti oleh peneliti. Hal tersebut menggambarkan bahwa meskipun belajar dimasa pandemi yang mengharuskan belajar dirumah, kami mencoba membimbing siswa dengan jumlah kelompok kecil (4-5 orang), hasilnya rataan kehadiran, pengumpulan tugas serta keaktifan dalam bertanya pun meningkat.
\end{abstract}

Kata kunci: kerja kelompok, motivasi belajar, matematika, belajar dimasa pandemi 


\section{Pendahuluan}

Genap 1 Tahun Pandemi ini kita lalui, Pembatasan Sosial Berskala Besar (PSBB) telah merubah berbagai tatanan kehidupan baik dari segi sosial, ekonomi hingga budaya, keagamaan dan pendidikan. Sebagaimana Peraturan Pemerintah Nomor 21 Tahun 2020 tentang Pembatasan Sosial Berskala Besar dalam Rangka Percepatan Penanganan Corona Virus Disease 2019 (COVID19) Pasal 4 poin 1 menjelaskan Pembatasan Sosial Berskala Besar paling sedikit meliputi : a. peliburan sekolah dan tempat kerja; b. pembatasan kegiatan keagamaan; dan/atau c. pembatasan kegiatan di tempat atau fasilitas umum.

Dalam dunia pendidikan, pendidikan dasar adalah sektor yang paling mengalami kebingungan karena dimasa ini anak belum tumbuh jiwa kemandirian belajarnya, selain dari itu anak membutuhkan berbagai aspek yang harus terpenuhi agar pembelajaran itu dapat meresap dalam pemikiran dan kehidupannya, karena pada hakikatnya proses pendidikan bukan hanya berbicara tentang transfer ilmu pengetahuan sebagaimana di jelaskan dalam Undang-Undang Republik Indonesia Nomor 20 Tahun 2003 tentang Sistem Pendidikan Nasional bahwa Pendidikan adalah usaha sadar dan terencana untuk mewujudkan suasana belajar dan proses pembelajaran agar peserta didik secara aktif mengembangkan potensi dirinya untuk memiliki kekuatan spiritual keagamaan, pengendalian diri, kepribadian, kecerdasan, akhlak mulia, serta keterampilan yang diperlukan dirinya, masyarakat, bangsa dan negara.

"PJJ bukanlah kebijakan Kemendikbud. Metode ini dipilih agar pendidikan tetap hadir, khususnya bagi anak-anak usia sekolah, dalam suasana yang menyenangkan dan aman." kata Nadiem dalam keterangan persnya, Kamis 10 September 2020 (Madkori, 2020). Tidak bisa dipungkiri, bahwa saat ini pendidikan mengalami dilematis yang teramat berat, disatu sisi kita menjaga keselamatan hidup kita dan anak-anak kita tapi disisi lain anak kita akan terus tumbuh dan berkembang dan mereka membutuhkan sebuah bekal yang benar dari sebuah pendidikan.

Motivasi (motivation) dapat diartikan sebagai kekuatan yang muncul dari dalam ataupun dari luar diri seseorang dan membangkitkan semangat serta ketekunan untuk mencapai sesuatu yang diinginkan (Iskandar, 2016), dikatakan oleh Sani (2013:49) jenis motivasi yaitu 1) motivasi ekstrintik muncul akibat insentif eksternal atau pengaruh dari luar anak didik, misalnya: dorongan, imbalan, atau hukuman. 2) motivasi internal muncul dari dalam diri 
seseorang untuk melakukan sesuatu, misalnya siswa belajar menghitung karena dia menyukai pelajaran tersebut. Sehingga pada akhirnya berhasilnya pendidikan siswa tergantung pada tanggungjawab guru dalam melakukankan tugasnya yaitu membangkitkan motivasi anak didik sehingga ia mau mengikuti pembelajaran (Majid, 2015).

Ini selaras dengan permasalahan yang kami temukan di lapangan, saat kami (Dosen dan mahasiswa) melakukan sebuah wawancara sederhana pada guru Kelas 3 SDN 2 Pangauban, tempat kami melakukan program PLP (Pengenalan Lapangan Persekolahan) 2020. Dalam wawancara yang dilakukan pada tanggal 20 Oktober 2020 lalu itu peneliti mendapatkan beberapa informasi dari ibu Euis Fauziah, S.Pd selaku wali kelas 3 SDN 2 Pangauban, menurutnya proses pembelajaran selama masa pandemi ini sangat membatasi proses penerimaan pembelajaran siswa, karena untuk di daerah Pangauban Cisurupan yang notabene mata pencaharian orang tua siswanya adalah pertanian dan perkebunan, orang tua mengeluhkan kesulitan mereka mendampingi siswa belajar secara daring dari rumah, dengan ragam kendala dari mulai waktu, sarana prasarana yang tidak memadai, hingga pada tingkat pemahaman orang tua terhadap materi yang diajarkan karena berdasar pada data orang tua siswa yang ada disekolah sekitar $62 \%$ ayah dan $74 \%$ ibu dari siswa hanya berpendidikan sekolah dasar dengan rata-rata usia 40 tahun.

Selain dari permasalahan pendampingan orang tua, Bu Euis pun menuturkan bahwa adanya penurunan motivasi belajar siswa dengan indikasi beberapa siswa mulai sulit mengerjakan tugas, beberapa orang tua mengeluhkan anaknya yang sulit sekali untuk mengerjakan tugas dirumah karena kebanyakan anak merasa bosan dan lebih memilih bermain diluar bersama temannya ketimbang belajar di rumah.

Apalagi dari awal baik siswa maupun orang tua siswa menganggap mata pelajaran matematika merupakan mata pelajaran yang dianggap sulit atau menyita daya berfikir siswa. Hal tersebut sesuai dengan hasil wawancara Ibu Nina selaku orang tua siswa kelas 3, yang menyatakan bahwa mereka kurang sekali menguasai mata pelajaran matematika sehingga berpengaruh pada pemberian motivasi belajar dan pada akhirnya anak-anaknya tidak ada keinginan dalam belajar.

Untuk mensiasati permasalahan tersebut banyak variasi metode yang dapat guru coba untuk menumbuhkan motvasi belajar siswa seperti halnya membentuk kerja kelompok. Menurut Sudjana (2010:140) kelebihan metode kerja kelompok memberi kesempatan yang luas bagi anak untuk 
mengungkapkan ide, tanggapan, pengalaman sehingga siswa aktif dan kegiatan belajar akan lebih bagus, menambah motivasi belajar peserta didik, menegakkan sikap saling menghargai pendapat teman, menumbuhkan kegairahan belajar anak didik, dengan menggunakan kerja kelompok dapat meningkatkan kedekatan antar siswa, partisipasi anggota diperlukan untuk melakukan kerja sama dalam menyelesaikan tugas kelompok yang diberikan oleh pengajar.

Berdasarkan pengembangan wawancara dengan Bu Euis sebelumnya, kami mendapatkan bahwa beliau bersedia menerapkan menerapkan metode pembelajaran yang kita tawarkan sebagai salah satu solusi meminimalkan permasalahan di kelas tersebut. Tatacara pembelajaran, bahan ajar yang kurang maksimal, alat pendukung pembelajaran, kami akan melengkapinya dan membantu membimbing siswa-siswanya yang sudah dikelompokan oleh pihak sekolah.

\section{Metodologi}

Untuk metode kami menggunakan metode penelitian kuantitatif, dimana metode penelitian yang berlandaskan pada filsafat positivisme, digunakan untuk meneliti pada populasi atau sampel tertentu, teknik pengambilan sampel pada umumnya dilakukan secara random, pengumpulan data menggunakan instrumen penelitian, analisis data bersifat kuantitatif/statistik dengan tujuan untuk menguji hipotesis yang telah ditetapkan. (Sugiyono, 2016: 14). Sedangkan cara penyajianya menggunakan deskriftif sehingga metode yang digunakan oleh kami adalah kuantitatif deskriftif dimana hasinya dapat mengungkapkan dan memecahkan permasalahan yaitu dengan menggambarkan dan memaparkan data sesuai dengan hasil penelitian sehingga bagi guru atau pun para mahasiswa kami kedepannya bisa memberikan gambaran metode apa yang tepat apabila pembelajaran dilaksanakan secara daring.

\section{Hasil dan Pembahasan}

\subsection{Hasil}

Data yang dikumpulkan peneliti pada penelitian ini adalah melalui penyebaran angket/kuisioner. Kuisioner merupakan teknik pengumpulan data yang dilakukan dengan cara memberi seperangkat pertanyaan atau pernyataan tertulis kepada responden ntuk dijawabnya (Sugiyono, 2016 : 199).

Kuisioner digunakan peneliti untuk mengetahui pendapat siswa terhadap variabel $(\mathrm{X})$ metode pembelajaran kerja kelompok pada pelajaran matematika 
sebanyak 15 item pernyataan, dan variabel (Y) motivasi belajar siswa sebanyak 16 item pernyataan, dengan total keseluruhan item pernyataan sebanyak 31 pernyataan. Berikut data yang didapatkan setelah penyebaran angket:

Tabel 1

Angket Kerja Kelompok pada pelajaran matematika dan Motivasi belajar

\begin{tabular}{|c|c|c|c|c|c|}
\hline \multicolumn{6}{|c|}{ Angket Kerja Kelompok Pada Pelajaran } \\
\hline No & $\begin{array}{c}\text { No } \\
\text { Pernyataan }\end{array}$ & Fi & F*Skor & $\%$ & Kategori \\
\hline 1 & 1 & 27 & 122 & 90,37 & $\begin{array}{c}\text { Sangat } \\
\text { Baik }\end{array}$ \\
\hline 2 & 2 & 27 & 107 & 79,26 & Baik \\
\hline 3 & 3 & 27 & 67 & 49,63 & $\begin{array}{c}\text { Kurang } \\
\text { Baik }\end{array}$ \\
\hline 4 & 4 & 27 & 80 & 59,26 & Cukup \\
\hline 5 & 5 & 27 & 87 & 64,44 & Cukup \\
\hline 6 & 6 & 27 & 116 & 85,93 & $\begin{array}{c}\text { Sangat } \\
\text { Baik }\end{array}$ \\
\hline 7 & 7 & 27 & 101 & 74,81 & Baik \\
\hline 8 & 8 & 27 & 92 & 68,15 & Baik \\
\hline 9 & 9 & 27 & 65 & 48,15 & Kurang \\
\hline 10 & 10 & 27 & 87 & 64,44 & Cukup \\
\hline 11 & 11 & 27 & 76 & 56,3 & Cukup \\
\hline 12 & 12 & 27 & 95 & 70,37 & Baik \\
\hline 13 & 13 & 27 & 87 & 64,44 & Cukup \\
\hline 14 & 14 & 27 & 77 & 57,04 & Cukup \\
\hline 15 & 15 & 27 & 106 & 78,52 & Baik \\
\hline & Rata-Rata & & 67,41 & Cukup \\
\hline
\end{tabular}

\begin{tabular}{|c|c|c|c|c|c|}
\hline \multicolumn{6}{|c|}{ Angket Motivasi Belajar (Y) } \\
\hline & $\begin{array}{c}\text { No } \\
\text { Pernyatan }\end{array}$ & Fi & F*Skor & $\%$ & Kategori \\
\hline 1 & 1 & 27 & 110 & 81,48 & Baik \\
\hline 2 & 2 & 27 & 99 & 73,33 & Baik \\
\hline 3 & 3 & 27 & 82 & 60,74 & Cukup \\
\hline 4 & 4 & 27 & 84 & 62,22 & Cukup \\
\hline 5 & 5 & 27 & 100 & 74,07 & Baik \\
\hline 6 & 6 & 27 & 99 & 73,33 & Baik \\
\hline 7 & 7 & 27 & 103 & 76,3 & Baik \\
\hline 8 & 8 & 27 & 101 & 74,81 & Baik \\
\hline 9 & 9 & 27 & 77 & 57,04 & Cukup \\
\hline 10 & 10 & 27 & 83 & 61,48 & Cukup \\
\hline 11 & 11 & 27 & 80 & 59,26 & Cukup \\
\hline 12 & 12 & 27 & 101 & 74,81 & Baik \\
\hline 13 & 13 & 27 & 94 & 69,63 & Baik \\
\hline 14 & 14 & 27 & 79 & 58,52 & Cukup \\
\hline 15 & 15 & 27 & 104 & 77,04 & Baik \\
\hline 16 & 16 & 27 & 96 & 71,11 & Baik \\
\hline & Rata-Rata & & 69,07 & Baik \\
\hline
\end{tabular}

Berdasarkan tabel diatas dapat disimpulkan bahwa, pengaruh Metode Pembelajaran Kerja Kelompok pada pelajaran matematika mendapat skor sebesar 67,41 kategori Cukup. Dan dari table di atas juga kita dapat melihat bahwa skor tertinggi diperoleh oleh item pernyataan nomor 1 dengan 
persentase $90,37 \%$ dimana mereka sudah saling mengenal karakter satu sama lainnya, kemudian skor terendah diperoleh item nomor 9 dengan persentase $48,15 \%$ dimana mereka merasa teman kelompoknya kebanyakan hanya mengobrol saat belajar.

Sedangkan untuk Motivasi Belajar mendapat skor sebesar 69,07 kategori Baik. Dari data tersebut juga dapat kita lihat bahwa skor tertinggi diperoleh oleh item pernyataan nomor 1 dengan persentase sebesar $81,48 \%$ dimana mereka merasa tertarik untuk mengikuti pembelajaran berkelompok, sedangkan skor terkecil diperoleh oleh item nomor 9 dengan persentase 57,04 $\%$ dimana hampir setengah lebih jumlah siswa merasa malu untuk bertanya saat mereka kurang memahami materi pembelajaran karena takut ditertawakan atau diejek teman-temannya.

\section{Tabel 2}

Uji Hipotesis

\begin{tabular}{|l|l|}
\hline $\mathrm{d}^{\wedge} 2$ & 897,5 \\
\hline $\mathrm{n}$ & 27 \\
\hline Nilai Koefisien Korelasi & 0,726 \\
\hline T hitung & 5,279 \\
\hline T tabel & 2,060 \\
\hline Keterangan & Ha Diterima \\
\hline
\end{tabular}

Berdasarkan data tabel diatas dapat kita lihat bahwa Ha diterima karena sesuai dengan kaidah keputusan jika T hitung $(5,279)>\mathrm{T}$ tabel $(2,060)$ maka Ha di terima, yang berarti terdapat pengaruh dari Metode Pembelajaran Kerja Kelompok pada pelajaran matematika terhadap Motivasi Belajar Siswa di masa pandemi Kelas 3 SDN 2 Pangauban.

\subsubsection{Hasil Uji Determinasi} dalam) (besar pengaruh/pengaruh

$$
\begin{aligned}
& D=r^{2} \times 100 \% \\
& D=0.726^{2} \times 100 \% \\
& D=52,71 \%
\end{aligned}
$$

\author{
3.1.2 Hasil Uji Epsilon \\ (faktor lain/pengaruh luar)$$
\varepsilon=100 \%-D
$$$$
\varepsilon=100 \%-52,71 \%
$$$$
\varepsilon=47,29 \%
$$

\subsection{PEMBAHASAN}

Dilihat dari hasil perhitungan diatas, terbukti bahwa koefisien korelasi signifikan ditunjukan dengan nilai $T_{\text {hitung }}$ sebesar 5,279. Nilai tersebut lebih 
besar dari nilai $t_{\text {tabel }}$ sebesar 2,060 $(5,279>2,060)$, ini menegaskan bahwa Ha diterima, maka dalam penelitian ini terdapat pengaruh antara Metode Pembelajaran Kerja Kelompok pada pelajaran matematika terhadap Motivasi Belajar Siswa di masa pandemi Kelas 3 SDN 2 Pangauban Cisurupan Garut.

Berdasarkan data penelitian diatas pula dapat dilihat bahwa nilai determinasi pengaruh Metode Pembelajaran Kerja Kelompok terhadap Motivasi Belajar Siswa dimasa pandemi ini adalah sebesar $52,71 \%$ dalam kategori sedang dengan tingkat hubungan sebesar 0,726 dalam kategori kuat. Daya determinasi tersebut lebih besar dari epsilon nya yakni sebesar 47,29\% yang dipengaruhi variabel lain yang tidak diteliti oleh penulis, seperti faktor perhatian guru, peran orang tua, motivasi luar maupun dalam lainnya serta lingkungan belajar siswa selama pandemi ini.

Berdasar pada hasil observasi melalui lembar pengamatan penelitian, Metode Pembelajaran Kerja Kelompok pada pelajaran matematika ini mengindikasikan adanya pengaruh terhadap Motivasi Belajar Siswa Kelas 3 SDN 2 Pangauban di masa pandemi, hal ini di tunjukan dengan adanya perubahan dari segi antusiasme belajar siswa yang awalnya ketika belajar mandiri di rumah siswa cenderung malas belajar setelah diterapkannya metode ini siswa menjadi menjadi lebih antusias untuk mengikuti pembelajaran. Kemudian dari segi semangat siswa pun menunjukan adanya peningkatan siswa mulai menunjukan gairah belajar dan mengikuti pembelajaran secara aktif. Selain dari itu kuantitas serta kualitas pengerjaan tugas siswa pun meningkat yang awalnya hanya sekitar $20 \%-30 \%$, kini hampir $80 \%$ - 90\% siswa selalu mengerjakan dan mengumpulkan tugas. Berdasarkan pengamatan tersebut dapat menegaskan bahwa pengaruh yang ditimbulkan dari penerapan Metode Pembelajaran Kerja Kelompok ini bersifat positif dalam pengembangan Motivasi Belajar Siswa Kelas 3 SDN 2 Pangauban.

Selama pandemi ini dengan adanya kebijakan social distancing anak-anak belajar secara mandiri dirumah dengan pemantauan secara daring dari pihak guru serta bimbingan langsung dari orang tua. Dengan berbagai macam kendalanya sistem pembelajaran jarak jauh ini lambat laun telah menurunkan motivasi belajar siswa. Sembari tetap memperhatikan protokol kesehatan jiwa pembelajar siswa harus terus dihidupkan dengan metode pembelajaran kerja kelompok terbatas ini, telah peneliti buktikan dinilai cukup berdampak pada peningkatan motivasi belajar siswa khususnya siswa kelas 3 SDN 2 Pangauban, meski dengan jumlah kelompok yang hanya 4-6 orang motivasi mereka kembali tumbuh dan terdorong, dengan indikasi siswa kembali 
mengikuti pembelajaran dengan antusias dan mampu mengerjakan tugastugas yang diberikan.

\section{Kesimpulan}

Berdasarkan hasil penelitian yang telah kami lakukan ada beberapa hal yang menjadi kesimpulan, yaitu:

1. Berdasarkan pengolahan data dengan analisis data yang menggunakan teknik perhitungan statistik melalui uji koefesien korelasi Rank Spearmen dari Pengaruh Metode Pembelajaran Kerja Kelompok pada pelajaran matematika (variabel X) dalam Meningkatkan Motivasi Belajar Siswa pada masa pandemi Covid-19 (variabel Y), didapatkan kriteria uji thitung>ttabel yaitu $(5,279>2,060)$, sehingga dapat ditarik kesimpulan bahwa Ha diterima, artinya dalam penelitian ini terdapat pengaruh positif dan signifikan dari variabel Metode Pembelajaran Kerja Kelompok pada pelajaran matematika terhadap motivasi belajar siswa pada pada masa pandemic Covid-19 di Kelas 3 SDN 2 Pangauban Cisurupan Garut. Adapun besar pengaruh yang didapatkan variabel $\mathrm{X}$ terhadap variabel $\mathrm{Y}$ adalah sebesar 52,71\% sedangkan sisanya sebesar $47,29 \%$ dipengaruhi oleh variabel lain yang tidak diteliti oleh peneliti dan diduga akan berpengaruh terhadap motivasi belajar siswa. Nilai tersebut menggambarkan kondisi bahwa variabel motivasi belajar siswa dapat dipengaruhi oleh metode pembelajaran kerja kelompok, dengan tingkat hubungan 0,726, yang mendapatkan kategori "kuat".

2. Metode Pembelajaran Kerja Kelompok pada pelajaran matematika (variabel X) sesuai dengan hasil angket adalah cukup. Hal ini dapat dilihat dengan nilai rata-rata dari variabel ini sebesar 91 dengan persentase sebanyak 67,41\% berada dalam kategori cukup.

3. Motivasi Belajar Siswa pada pada masa pandemi Covid-19 (variabel Y) sesuai dengan hasil angket adalah baik. Hal ini dapat dilihat dengan nilai rata-rata dari variabel ini sebesar 93,25 dengan persentase sebanyak 69,07\% berada dalam kategori baik.

\section{Daftar Pustaka}

Iskandar. (2016). Implementasi Teori Hirarki Kebutuhan Abraham Maslom terhadap peningkatan kinerja pustakawan. Jurnal Ilmu Perpustakaan, Informasi, dan Kearsipan Khizanah Al- Hikmah, hlm 24-34. ISSN: 2354-9629. 
Madkori, Yopi (2020). Nadiem Sebut Pendidikan Banyak Berubah Untuk Hadapi Pandemi Covid-19. https://www.liputan6.com/news/read/435468/ nadiem-sebutpendidikan-banyak-berubah-untuk-hadapi-pandemi-covid-19.html

Majid, Abdul. (2015). Straregi Pembelajaran. Bandung: PT Remaja Rosdakarya Offset.

Pemerintah Nomor 21 Tahun 2020 tentang Pembatasan Sosial Berskala Besar dalam Rangka Percepatan Penanganan Corona Virus Disease 2019 (COVID-19)

Sani, Ridwan Abdullah. (2013). Inovasi Belajar. Jakarta: PT Bumi Aksara.

Sudjana, S. (2010). Metode dan Teknik Pembelajaran Partisipatif. Bandung: Falah Prodution

Sugiyono. (2016). Metode Penelitian Pendidikan Kuantitatif, Kualitatif, dan $R \& D$. Bandung: Alfabeta. 